\title{
Aspek Hukum Pemegang Saham dalam Perseroan dengan Satu Pemegang Saham (Single Share-holder) (Studi Komparasi Indonesia dengan China)
}

\author{
Indah Siti Aprilia \\ Mahasiswa Magister Hukum \\ Fakultas Hukum Universitas Indonesia \\ indahsitiaprilia@gmail.com
}

\begin{abstract}
Abstrak
Pemerintah bertujuan menciptakan kondisi usaha yang kondusif dengan Undang Undang Cipta Kerja (UU CK). Salah satu isi UU CK adalah mengubah beberapa pasal pada Undang-Undang Perseroan Terbatas dan menghadirkan suatu trobosan yaitu Perseroan Perorangan bagi UMKM yang dinilai sebagai bentuk trobosan dalam pembangunan perekonomian nasional. Penelitian bertujuan untuk mengetahui bagaimana aspek hukum perseroan dalam UUCK dan dalam UUPT dengan dibandingkan dengan negara China.. Penelitian ini merupakan penelitian juridis normatif. Penelitian ini menyimpulkan bahwa di Indonesia dan di China sama-sama memiliki suatu perseroan dengan satu pemegang saham atau one shareholder. Akan tetapi yang membedakan daripada Indonesia dan China ini adalah dalam mekanisme pendaftaran perseroan tersebut dan aspek tanggung jawab yang diemban oleh satu pemegang saham dalam perseroan tersebut.
\end{abstract}

\section{Kata Kunci : Perseroan Terbatas, Single Share-holder, Indonesia, China}

\begin{abstract}
The government aims to creats conducive business conditions with the Job Creation Act (UUCK). One of the contents of the UUCK is to amend several article in the Limited Liability Company Law and present a breakthrough, namely Individual Company for MSME's that can be used as a form of breakthrough in the development of the national economy. This study aims to see how the legal aspect of the company in UUCK and in the UUPT are compared to that of China. This research is a normative juridical study. This study concludes that both of Indonesia and China have a company with a one shareholder. However, what is determined by Indonesia and China is in the mechanism of the registration of the company and the responsibilities assumed by one shareholder in the company.
\end{abstract}

Keyword: Accountability of the Company, Single Share-holder, Indonesia, China 


\section{PENDAHULUAN}

Kemajuan suatu negara dapat tercermin dengan adanya sebuah kebijakan yang dibuat untuk terus menerus meningkatkan kesejahteraan dan kemakmuran rakatnya. Di Indonesia sendiri sudah menjadi bagian dari tujuan negara yang termaktub dalam Aline keempat pembukaan UUD NRI 1945 yakni “...memajukan kesejahteraan umum..." sehingga sebuah kemakmuran dan kesejahteraan yang merata merupakan sebuah tujuan suci bangsa Indonesia.

Memperhatikan tujuan negara tersebut, maka dalam dunia usaha yang merupakan sebuah kegiatan yang mendorong roda perekonomian membawa angin yang sangat penting bagi peradaban bangsa. Karena dunia usaha yang salah satu bentuknya adalah dengan mendirikan perseroan tentunya menghasilkan pajak bagi negara, menjadi tumpuan bagi masyarakat mencari rejeki karena menciptakan lapangan pekerjaan bagi masyarakat banyak, dan dapat membawa negara dan masyarakat kepada peningkatan pengetahuan dan teknologi yang mengacu negara kearah modernisasi dan pembangunan. ${ }^{1}$

Keberadaan perusahaan sangat berperan dalam memajukan suatu masyarakat, daerah dan negara. Sehingga dapat mewujudkan kesejahteraan masyarakat. Hal ini dengan adanya suatu perusahaan di suatu daerah, maka akan dapat menyerap tenaga kerja. ${ }^{2}$

Akan tetapi, ketika memperhatikan kondisi di Indonesia saat ini, pertumbuhan jumlah usia produktif yang sangat tinggi di Indonesia belum mampu diimbangi dengan kualitas SDM dan ketersediaan lapangan kerja. Oleh karenanya guna mencapai tujuan negara memajukan kesejahteraan umum dan dalam rangka memenuhi hak-hak atas pekerjaan dan penghidupan yang layak sebagaimana diamaatkan dalam UUD NRI 1945, Pemerintah memandang perlu dikeluarkan suatu kebijakan baru guna mengatur strategi mencapat tujuan negara tersebut. Upaya strategis yang dilakukan dalam rangka penciptaan lapangan pekerjaan secara gaaris besar dilakukan melalui 3 (tiga)

\footnotetext{
${ }^{1}$ BPHN, Laporan Akhir Tim Analisis dan Evaluasi Hukum tentang Bentuk-Bentuk Badan Usaha Di Luar PT dan Koperasi, Tahun 2003

2 Darosa Mahaparsa, Tanggungjawab Pemegang Saham terhadap kerugian yang ditimbulkan akibat penghentian operasional perusahaan menurut hukum positif di Indonesia, Jurnal Ilmiah Fakultas Hukum Universitas Mataram,2018 hal i
} 
upaya, yakni: (a) Peningkatan Investasi; (b) Penguatan UMKM; dan (c) Peningkatan kualitas SDM (ketenagakerjaan) Indonesia. $^{3}$ Kemudian Pemerintah rumuskan dalam sebuah politik hukum bernama Undang-Undang Cipta Kerja yang diundangkan melalui Undang-Undang Nomor 11 Tahun 2020 tentang Cipta Kerja (UUCK).

Melalui UUCK ini terdapat sebuah mekanisme yang dianggap baru padahal juga tidak, dimana telah tertanam sebuah pemikiran tentang sebuah pendirian perseroan terbatas adalah sebuah perkumpulan sero (modal) yang konsekuensi dari perkumpulan modal tersebut ialah pendirian dan kepemilikan saham suatu perseroan wajib oleh dua orang atau lebih, sebagaimana dalam UndangUndang Perseroan Pasal 7 ayat (1) dikatakan "Perseroan didirikan oleh 2 (dua) orang atau lebih dengan akta notaris yang dibuat dalam bahasa Indonesia”. Namun dapat dikatakan bukan sebuah hal yang baru karena dalam ketentuan lebih lanjut dalam UUPT Pasal 7 ayat (7) dikatakan bahwa "Ketentuan yang mewajibkan Perseroan didirikan oleh 2 (dua) orang atau lebih sebagaimana dimaksud pada ayat (1), dan ketentuan pada ayat (5), serta ayat (6) tidak berlaku bagi: a. Persero yang seluruh sahamnya dimiliki oleh negara; atau b. Perseroan yang mengelola bursa efek, lembaga kliring dan penjaminan, lembaga penyimpanan dan penyelesaian, dan lembaga lain sebagaimana diatur dalam undangundang tentang Pasar Modal." Dalam UUCK ini dirancang sebuah aturan mengenai pendirian dan operasinal perseroan terbatas bagi UMKM oleh satu rang pendiri atau pemegang saham (single shareholder).

Pemerintah menganggap adanya trobosan baru ini sebagai pemberian kemudahan, perlindungan dan pemberdayaan pada UMKM serta perkoprasian. Akan tetapi yang menjadi pertanyaan bersama adalah bagaimana dengan tanggung jawab dari pemegang saham dalam Perseroan Perseorangan. Hal ini menjadi menarik, karena dalam sebuah perseroan terbatas, tanggung jawab terbatas merupakan suatu hal yang fundamental yang membedakannya dengan badan usaha lainnya, dimana tanggung jawab terbatas merupakan suatu kondisi dimana pemegang saham atau shareholder dari suatu perseroan hanya

${ }^{3}$ Naskah Akademik RUU Cipta Kerja, hal 109 
bertanggung jawab sebatas pada jumlah saham yang mereka miliki di perseroan tersebut.

Single shareholder ini berkembang sebagai tren perkembangan hukum perusahaan di dunia yang kini diadopsi di Indonesia harus berkembang sesuai dengan tujuannya yaitu memudahkan masyarakat Indonesia yang ingin berusaha mendirikan sebuah usaha sebagai jalan mencapai kesejahteraan. Perlu kiranya konsep single shareholder ini diimplementasikan tanpa merusak prinsip tanggung jawab terbatas sebagai fundamental dari perseroan dan yang membedakannya dengan badan usaha lain, serta perlu memperhatikan keterpisahan individu dan perusahaan (separate legal personality) yang juga merupakan karakter khusus dari perseroan terbatas yang esensinnya adalah bahwa suatu perusahaan dalam hal ini adalah perseroan terbatas, mempunyai personalitas atau kepribadian yang berbeda dari orang yang menciptakannya. ${ }^{4}$ Oleh karenanya dalam tulisan ini akan mengkaji bagaimana aspek hukum dari pemegang saham perseroan perorangan dengan membandingkan perseroan perseorangan atau perseroan dengan satu pemagang yang akan direalisasikan Pemerintah melalui UUCK dengan perseroan dengan satu pemegang saham di China.

Komparasi dengan China dilakukan karena selain memiliki kesamaan dengan Indonesia, yakni merupakan suatu negara di kawasan Asia, dan sama-sama memiliki pengaturan tentang perseroan dengan satu pemegang saham yang dalam Company Law of the People's Republic of China 2014 disebut dengan Special Provisions on One-Person Limited Liability Companies.

Oleh karenanya dalam tulisan ini mengambil judul "Aspek Hukum Pemegang Saham dalam Perseroan dengan Satu Pemegang Saham (Single Share-holder) (Studi Komparasi Indonesia dengan China)

\section{METODE PENELITIAN}

\footnotetext{
${ }^{4}$ Sandra Dewi, Pengaturan Perseroan Terbatas Terhadap Kasus-Kasus di Berbagai Negara dalam Hal tanggungjawab terbatas atau limited liability, Ensiklopedia of Journal Vol 1 No, 1 Oktober 2018, hal. 128
} 
Penelitian ini menggunakan metode dalam pelaksanaan penelitian. Dalam pengumpulan bahan dan materi didasarkan pada penelitian hukum normatif. Penelitian hukum normatif merupakan penelitian kepustakaan atau studi dokumen, yaitu penelitian dilakukan atau ditujukan pada peraturan-peraturan tertulis atau disebut juga dengan data sekunder.

\section{HASIL PENELITIAN DAN PEMBAHASAN}

\section{Kebijakan Hukum Perseroan terkait Perseroan dengan Satu Pemegang Saham di China dan Indonesia}

Dalam hal mekanisme pertanggung jawaban dalam sebuah perseroan bermula dari Kasus Salomon vs Salomon \&Co. dimana Mr. Salomon seorang penjual sepatu yang mendirikan suatu perusahaan bernama Salomon \& Co Ltd bersama dengan ke-6 anggota keluarga lainnya. Pada awalnya, Mr. Salomon adalah seorang penjual sepatu yang bekerja sendiri (sole trader). Dengan demikian, Mr. Salomon memiliki tanggung jawab pribadi atas segala hutang yang timbul oleh usahanya itu. Namun, Mr. Salomon yang kemudian mendirikan Salomon \& Co Ltd berganti kedudukan sebagai managing partner yang juga menjadi pemegang saham pada perusahaan yang dibentuknya itu, sehingga dari yang sebelumnya Mr. Salomon memiliki personal liability atau unlimited liability atas seluruh hutang yang timbul, berubah menjadi limited liability dikarenakan Mr. Salomon berkedudukan sebagai pemegang saham di Salomon \& Co Ltd. Setelah itu salah satu pemegang surat hutang meminta agar Mr. Salomon menyerahkan jaminan berupa asset dari perusahaannya, namun hal tersebut tidak dapat dilakukan oleh Mr. Salomon. Mr Broderip, pemegang surat hutang, menyatakan bahwa Salomon \& Co Ltd adalah sebagai 'alat' atau 'agent' dari Mr. Salomon sehingga layak untuk dinyatakan pailit dan dilikuidasi. Atas alasan tersebut, Court of Appeals menguatkan hal tersebut dengan melihat alasan kepada motif dari Mr Salomon dan anggota keluarga lainnya dalam menjalankan perusahaan. Court of Appeals, dalam hal ini Kay LJ, melihat bahwa keenam anggota keluarga lainnya tidak memliki niatan untuk berperan dalam bisnis tersebut, namun hanya bertindak sebagai 
pemegang saham untuk memenuhi persyaratan teknis pendirian perusahaan yang diatur oleh the Joint Stock Companies Act 1844. Sehingga atas putusan Court of Appeals tersebut, Mr. Salomon dinyatakan mampu untuk menjamin kerugian perusahaannya ${ }^{5}$ Kasus Salomon vs Salomon \& Co tersebut menjadi pelajaran yang sangat penting untuk dapat membedakan terkait dengan konsep limited liability dan konsep corporate personality. Mana yang harus menjadi tanggung jawab pemegang saham dan mana yang harus menjadi tanggung jawab perseroan, jika pada suatu ketika dalam hubungan hukum dengan pihak ketiga Perseroan merugikan pihak ketiga.

Di Indonesia sendiri, jika kita mengacu pada UUPT memberikan pengaturan terhadap prinsip piercing the corporate veil atau lifting the veil yang artinya menembus cadar perusahaan atau membuka tabir perusahaan. ${ }^{6}$

Pasal 3 Ayat (1) Undang-Undang Nomor 40 Tahun 2007 mengatur mengenai prinsip tanggung jawab terbatas atau limited liability atau limitatief aansprakelijkheid sedangkan Pasal 3 Ayat (2) mengatur mengenai batasan terhadap prinsip limited liability tersebut. Selain itu, prinsip piercing the veil ini dapat ditemukan pula pada ketentuan yang diatur dalam Pasal 7 Ayat (6) UU PT yang menyatakan bahwa "dalam hal jangka waktu sebagaimana dimaksud pada Ayat (5) telah dilampaui, pemegang saham tetap kurang dari dua orang, pemegang saham bertanggung jawab secara pribadi atas segala perikatan dan kerugian perseroan, dan atas permohonan pihak yang berkepentingan, pengadilan negeri dapat membubarkan Perseroan tersebut”.

Kemudian sebuah kebijakan baru muncul yaitu dengan hadirnya UUCK dengan memperbolehkan UMKM mendirikan sebuah Perseroan Perseorangan dengan Satu Pemegang Saham. Dalam kajian tulisan ini, membandingkan dengan China dikarenakan China merupakan suatu negara yang juga sangat pesat dalam aspek bisnisnya dan banyak menarik investor dan menjadi salah satu pasar paling aktif dalam menggaet investor. ${ }^{7}$

\footnotetext{
${ }^{5}$ Alan Dignam \& John Lowry, 'Company Law', Sixth Edition, Oxford University Press. page.20

${ }^{6}$ I G. Rai Widjaya, Hukum Perusahaan, Ksaint Black, Bekasi, 2003. Hal. 146

${ }^{7}$ Randall K, Morck, A History of Corporate Governance around the world: Family Business Groups to Professional managers, University of Chicago Press 2005 page 6
} 
Pertama bila kita melihat daripada perbandingan kriteria UMKM antara Indonesia dengan China, di Indonesia berdasarkan bentuk hukumnya, di China UMKM dapat termasuk pada bentuk usaha (1) Sole Proprietorship, (2) Partnership (ordinary partnership, limited partnership, special partnership; (3) Limited Liability Company; (4) One Person Limited Liability Company; dan (5) Wholly Owned Foreign Enterprise. Sedangkan di Indonesia, mulai tahun 2020 ini diubah sebuah politik hukum bahwa UMKM dapat berbentuk hukum (1) Perusahaan Perseorangan (Sole Proprietoship); (2) Persekutuan Perdata (maatschap) (3) CV (Persekutuan Komanditer); (4) Firma (Persekutuan dengan Firma); (5) Perseroan Terbatas; dan (6) Koperasi.

Di Indonesia sendiri, pengaturan berkaitan dengan Badan Hukum Perseroan diatur lebih lanjut dengan Undang-Undang Nomor 40. Tahun 2007 tentang Perseroan Terbatas yang seiring dengan berjalannya waktu, dilakukan sebuah pembaharuan hukum dengan Hadirnya Undang-Undang Nomor 11 Tahun 2020 tentang Cipta Lapangan Kerja yang mengusung konsep Omnibus Law. Sedangkan merujuk pada negara yang dijadikan perbandingan yakni di China, diatur dalam sebuah Undang-Undang yaitu Company Law of the People's Republic of China 2018.

Khusus berkenaan dengan Perseroan Perseorangan atau Perseroan dengan satu pemegang saham untuk UMKM baru diatur sejak diundangkannya UU No. 11 Tahun 2020 tentang Cipta Kerja. Sedangkan di China sudah mengenal single shareholder ini dengan sebutan One Person Limited Liability Companies. Hal ini diatur dalam Section 3 Company Law of the People's Republic of China 2018 yaitu Special Provisions on One-Perseon Limited Liability Companies.

Dalam Bagian kelima UUCK Pasal 109 tentang perubahan UU PT dalam Pasal 1 dinyatakan:

"Perseroan Terbatas, yang selanjutnya disebut Perseroan, adalah badan hukum yang merupakan persekutuan modal, didirikan berdasarkan perjanjian, melakukan kegiatan usaha dengan modal dasar yang seluruhnya terbagi dalam saham atau Badan Hukum perorangan yang memenuhi kriteria Usaha Mikro 
dan Kecil sebagaimana diatur dalam peraturan perundangundangan mengenai Usaha Mikro dan Kecil.”

Kalimat "Badan Hukum perorangan yang memenuhi kriteria Usaha Mikro dan Kecil sebagaimana diatur dalam peraturan perundangundangan mengenai Usaha Mikro dan Kecil” inilah yang menjadikan aturan baru yang melegalkan sebuah UMKM dengan satu orang pemegang saham dapat mendirikan sebuah badan hukum yang dinamakan Perseroan Perorangan.

Lebih lanjut dipertegas dengan Pasal 7 ayat (7) yaitu :

"Ketentuan yang mewajibkan Perseroan didirikan oleh 2 (dua) orang atau lebih sebagaimana dimaksud pada ayat (1), ayat (5), serta ayat (6) tidak berlaku bagi:

a. Persero yang seluruh sahamnya dimiliki oleh negara;

b. Badan Usaha Milik Daerah;

c. Badan Usaha Milik Desa;

d. Perseroan yang mengelola bursa efek, Lembaga kliring dan penjaminan, lembaga penyimpanan dan penyelesaian, dan lembaga lain sesuai dengan Undang-Undang tentang Pasar Modal; atau

e. Perseroan yang memenuhi kriteria untuk Usaha Mikro dan Kecil."

Kendati masih banyak tafsir mengenai definisi Perseroan Perseorangan dalam UUCK ini dikalangan banyak ahli yang menilai bahwa redefinisi Pasal 1 dari UUPT yang dianggap tumpang tindih dengan ditambahkannya satu poin huruf e dalam Pasal 7 ayat (7) nya. Akan tetapi dapat dikatakan hal ini dapat saling mempertegas bahwa di Indonesia kini sudah melegalkan bahwa UMKM dapat mendaftarkan sebagai Perseroan.

Sedangkan dalam Company Law of the People's Republic of China 2018 definisi tentang One Person Limited Liability Companies diatur sebagai berikut:

\section{Article 57}

This Section shall be applicable to the establishment and the organizational structure of a one-person limited liability company. In the 
absence of pertinent provisions in this Section, Section 1 and Section 2 of this Chapter shall apply. For the purpose of this Law, a one-person limited liability company shall refer to a limited liability company comprising only one natural person shareholder or one legal person shareholder.

Dalam peraturan Company Law of the People's Republic of China 2018 juga di berikan pengecualian bahwa perseorangan tersebut hanya dapat mendirikan satu perseroan terbatas saja dan dilarang berinvestasi dalam pendirian perseroan terbatas lainnya. Penulis berpendapat bahwa pengaturan Article 58 Company Law of the People's Republic of China 2018 ini ditujukan sebagai bentuk perlindungan hukum terhadap keberlangsungan Perseroan dengan satu Pemegang saham tersebut.

\section{Article 58}

One natural person can only establish one one-person limited liability company which is prohibited from investing in the establishment of another one-person limited liability company.

Selanjutnya dalam Article 59 Company Law of the People's Republic of China 2018 juga diatur bahwa dalam mekanisme pendaftaran One Person Limited Liability Company diatur bahwa pendaftarannya harus menunjukan izin usaha dan kekayaannya.

\section{Article 59}

A one-person limited liability company shall indicate, in its company registration, whether it is wholly owned by a natural person or a legal person. The same shall also be stated in the business license of the company.

\section{Article 60}

The articles of association of a oneperson limited liability company shall be formulated by the shareholder.

\section{Article 61}


A one-person limited liability company has no shareholders' meeting. Where the shareholder makes a decision listed in Paragraph 1 of Article 37 of this Law, the decision shall be made in writing, and shall be prepared and made available at the company after the shareholder has affixed his/her signature thereto.

Hal yang sama juga berlaku di Indonesia, dalam hal perseroan terbatas perseorangan, berdasaarkan Pasal 153A-153B UUCK pendaftaran tersebut dilakukan dengan membuat surat pernyataan pendirian berbahasa Indonesia yang berisikan maksud dan tujuan, kegiatan usaha, modal dasar, dan keterangan lain yang berkaitan dengan pendirian Perseroan yang didaftarkan secara elektronik kepada Mentri dengan mengisi format isian. Kendati demikian, mekanisme tersebut akan diatur lebih lanjut dalam sebuah Peraturan Pemerintah. Akan tetapi hingga tulisan ini dibuat belum ada Peraturan Pemerintah yang mengaturnya.

Pasal 153A

(1) Perseroan yang memenuhi kriteria Usaha Mikro dan Kecil dapat didirikan oleh 1 (satu) orang.

(2) Pendirian Perseroan untuk Usaha Mikro dan Kecil sebagaimana dimaksud pada ayat (1) dilakukan berdasarkan surat pernyataan pendirian yang dibuat dalam Bahasa Indonesia.

(3) Ketentuan lebih lanjut mengenai pendirian Perseroan untuk Usaha Mikro dan Kecil diatur dalam Peraturan Pemerintah.

Pasal 1538

(1) Pernyataan pendirian sebagaimana dimaksud dalam Pasal 153A ayat (2) memuat maksud dan tujuan, kegiatan usaha, modal dasar, dan keterangan lain berkaitan dengan pendirian Perseroan.

(2) Pernyataan pendirian sebagaimana dimaksud padaayat (1) didaftarkan secara elektronik kepada Menteri dengan mengisi format isian. 
(3) Ketentuan lebih lanjut mengenai materi pernyataan pendirian sebagaimana dimaksud pada ayat (1) dan format isian sebagaimana dimaksud pada ayat (2) diatur dalam Peraturan Pemerintah.

Penulis berpendapat bahwa, idealnya dalam pendaftaran perseroan perseorangan ini tidak hanya mengisi formular secara elektronik kepada Menteri. Akan tetapi surat pernyataan yang dibuat, dan saham yang akan ditanamkan kepada perseroan tersebut harus juga dibuat secara legal dan valid, tidak dibuat hanya oleh diri pribadi pendiri perseroan perorangan untuk menghindari kekosongan hukum yang mungkin terjadi di kemudian hari. Hendaknya surat-surat tersebut dibuat dihadapan notaris sebagai pejabat publik perwakilan negara. Dan peran notaris ini dapat juga dijadikan sebagai upaya penyuluhan hukum pertama pada calon pendiri perseroan tersebut. ${ }^{8}$

Hal ini juga berkaitan dengan perseroan terbatas yang merupakan subjek hukum yang tentunya akan berakibat perseroan terbatas ini berhak menjadi pemegang hak dan kewajiban, termasuk menjadi pemilik dari suatu benda atau harta kekayaan tertentu. Karena perseroan terbatas adalah sesuatu hal yang lahir sebagai badan hukum, tercipta melalui proses hukum, maka disebut sebagai makhluk badan hukum yang berwujud artificial yang dicipta melalui proses hukum. ${ }^{9}$ Perseroan ini dianggap seperti manusia yang bisa dimintai pertanggungjawabannya bila melakukan perbuatan hukum. ${ }^{10}$ Sehingga hendaknya perlu juga mendapatkan pengawasan dari notaris dalam pembuatan artificial person tersebut.

Lebih lanjut dalam aspek pertanggungjawaban dari Perseroan Peroarangan ini, di China aspek pertanggungjawabannya diatur dalam Article berikut:

\section{Article 62}

${ }^{8}$ Siti Fauziah Dian Novita Sari, Peran Notaris Dalam Proses Pembuatan Akta Pendirian Perseroan Terbatas, Jurnal Lex Renaissance, No. 2 Vol. 3 Juli 2018.hal 410

${ }^{9}$ M. Yahya Harahap, Hukum Perseroan Terbatas, Jakarta: Sinar Grafika, Cet. ke-3, 2011. hal. 36

${ }^{10}$ Adib Bahari, Prosedur Cepat Mendirikan Perseroan Terbatas, Yogyakarta: Pustaka Yustisia, 2010. hal.7 
A one-person limited liability company shall prepare financial and accounting reports at the end of each fiscal year, and such reports shall be audited by an accounting firm.

\section{Article 63}

Where the shareholder of a oneperson limited liability company is unable to prove that the property of the company is independent of his/her own property, the shareholder shallbear joint and several liabilities for the debts of the company.

Berdasarkan article diatas bahwa pemegang saham dari sebuah perseroan perseorangan ini harus menyiapkan laporan keuangan setiap tahun yang akan diaudit oleh kantor akuntan. Dan ketika pemegang saham satu orang tersebut ternyata tidak dapat membuktikan bahwa saham dari perusahaan tersebut adalah miliknya dan tidak mampu membuktikan hasil daripada temuan dari kantor akuntan tersebut, maka pemegang saham tersebut bertanggung jawab secara individu dan menanggung daripada hutang perusahaan.

Berbeda halnya dengan yang dikeluarkan sebagai kebijakan Pemerintah Indonesia melalui UUCK, pada Pasal 153 J diatur sebagai berikut:

(1) Pemegang saham Perseroan untuk Usaha Mikro dan Kecil tidak bertanggung jawab secara pribadi atas perikatan yang dibuat atas nama Perseroan dan tidak bertanggung jawab atas kerugian Perseroan melebihi saham yang dimiliki.

(2) Ketentuan sebagaimana dimaksud pada ayat (1) tidak berlaku apabila:

a. Persyaratan Perseroan sebagai badan hukum belum atau tidak terpenuhi;

b. Pemegang saham yang bersangkutan, baik langsung maupun tidak langsung dengan iktikad buruk memanfaatkan Perseroan untuk kepentingan pribadi;

c. Pemegang saham yang bersangkutan terlibat dalam perbuatan melawan hukum yang dilakukan oleh Perseroan; atau

d. Pemegang saham yang bersangkutan, baik langsung maupun tidak langsung secara melawan hukum menggunakan kekayaan Perseroan, 
yang mengakibatkan kekayaan Perseroan menjadi tidak cukup untuk melunasi utang Perseroan.

\section{PENUTUP}

Kendati Pemerintah Indonesia dan China memiliki berbagai kesamaan seperti sama-sama memiliki pengaturan tentang perseroan dengan satu pemegang saham yang dalam Company Law of the People's Republic of China 2018 dan di Indonesia dengan hadirnya UUCK ternyata terdapat beberapa perbedaan seperti dari mekanisme pendaftaran untuk perseroan dengan satu pemegang saham di China pendaftarannya harus menunjukan izin usaha dan kekayaannya dan di Indonesia dengan melakukan pendaftaran ke mentri hukum dan HAM dan mekanismenya masih dalam tahap penyusunan peraturan pemerintah.Begitupun dengan aspek pertanggungjawbaan, di China aspek pertanggungjawaban ini dilakukan oleh pemegang saham satu orang tersebut secara individual, sedangkan dalam rumusan UUCK ditentukan tidak bertanggungjawab secara pribadi atas perikatan yang dibuat atas nama Perseroan dan bertanggungjawab tidak melebihi saham yang dimiliki dalam perseroan perorangan tersebut.

\section{Saran}

Hendaknya dalam pengimplementasian hadirnya sebuah trobosan baru yaitu Perseroan Perorangan khusus untuk pelaku UMKM di dalam rumusan UU Cipta Lapangan Kerja segera dibuat aturan teknis yaitu peraturan pemerintah yang mengatur implementasi daripada pasal-pasal yang ada dalam UUCK tersebut.

\section{DAFTAR PUSTAKA}

Indonesia, Undang-Undang Nomor 11 Tahun 2020 tentang Cipta Kerja, LN No.245 Tahun 2020

Indonesia, Undang-Undang Nomor 40 Tahun 2007 tentang Perseroan Terbatas. LN No.106 Tahun 2007 
China, Company Law of the People's Republic of China 2018 Amandement.

Bahadi,Adib. Prosedur Cepat Mendirikan Perseroan Terbatas. Yogyakarta: Pustaka Yustisia. 2010.

BPHN. Laporan Akhir Tim Analisis dan Evaluasi Hukum tentang Bentuk-Bentuk Badan Usaha Di Luar PT dan Koperasi, Tahun 2003

Dewi, Sandra. Pengaturan Perseroan Terbatas Terhadap Kasus-Kasus di Berbagai Negara dalam Hal Tanggungjawab Terbatas atau Limited Liability. Ensiklopedia of Journal Vol 1 No, 1 Oktober. 2018

Dignam,Alan \& John Lowry. Company Law,Sixth Edition. Oxford University Press.

Harahap, M. Yahya. Hukum Perseroan Terbata. Jakarta: Sinar Grafika, Cet. ke-3. 2011

K,Randall \& Morck. A History of Corporate Governance Around the World: Family Business. Groups to Professional Managers. University of Chicago Press.2005

Mahaparsa, Darosa. Tanggungjawab Pemegang Saham Terhadap Kerugian yang Ditimbulkan Akibat Penghentian Operasional Perusahaan Menurut Hukum Positif di Indonesia. Jurnal Ilmiah Fakultas Hukum Universitas Mataram. 2018

Naskah Akademik RUU Cipta Kerja

Sari, Siti Fauziah Dian Novita. Peran Notaris Dalam Proses Pembuatan Akta Pendirian Perseroan Terbatas. Jurnal Lex Renaissance. No. 2 Vol. 3 Juli 2018.

Widjaya, I G. Rai. Hukum Perusahaan. Bekasi : Ksaint Black. 2003. 